\title{
RARE AND MARGINAL WINTER PASSERINE BIRDS IN MANITOBA
}

PETER TAYLOR, Box 597, Pinawa, MB. ROE 1 LO and RUDOLF F. KOES, 135 Rossmere Crescent, Winnipeg, MB. R2K OG1

Introduction Artificial feeding has dramatically altered the winter distribution of some North American birds. For example, Kaufmann has suggested that a "beneficent Maginot Line" of feeders has stemmed the flow of winter finches that formerly invaded much of the northern United States at irregular intervals. ${ }^{5}$ Artificial feeding has also led to northward extensions of winter ranges: a welldocumented example is the Mourning Dove in Ontario. ${ }^{1}$ In addition, feeders allow "half-hardy" birds such as blackbirds and sparrows to linger and sometimes survive the winter well north of their usual range limits. Blom described the need for information on the status and survival of birds occurring north of their usual range in winter. ${ }^{3}$ This article documents the status of rare and marginal winter passerines in Manitoba.

Scope and methods In the most recent Manitoba bird checklist, only 13 passerine species are described as fairly common, common or abundant in parts of Manitoba in winter: Gray Jay, Blue Jay, Black-billed Magpie, Common Raven, Black-capped Chickadee, White-breasted Nuthatch, Bohemian Waxwing, European Starling, Snow Bunting, Pine Grosbeak, Common Redpoll, Evening Grosbeak and House Sparrow. ${ }^{12}$ White-winged and Red Crossbills are irruptive, and sometimes overwinter in Manitoba in substantial numbers. Three other species are uncommon, but regular and widespread: Boreal Chickadee, Northern Shrike, and Hoary Redpoll. A further
55 passerine species have been reported in Manitoba in winter (i.e. December to March) and they are the subject of this article. These species fall into four broad categories:

(a) Marginal wintering species for which southern Manitoba lies at the northern edge of their winter range. Their presence is considered normal but numbers fluctuate from year to year.

(b) Stragglers which breed regularly in Manitoba but normally winter farther south. Of course, individuals that overwinter in Manitoba do not necessarily belong to Manitoba breeding populations.

(c) Rare permanent residents at the northern margin of their yearround range.

(d) Vagrants which are unusual in Manitoba (or in a specific region) at any season.

We have estimated the relative abundance and frequency of these species based on available records from 22 winters, 1973-74 to 1994-95 (up to January 1995), and the following criteria: accidental (three or fewer records); occasional (four or more records from fewer than 10 of the 22 winters with no daily counts of more than three individuals); rare (recorded in 10 or more of the 22 winters with no daily counts of more than five individuals); regular (recorded in 10 or more of the 22 winters with daily counts sometimes exceeding five 
individuals; and sporadic (rare or uncommon in some winters but observed in hundreds or thousands in other winters).

We also distinguish between attempted overwintering by birds seen in January and February, and successful overwintering by birds known to survive beyond March 1. Feeder visitors often become increasingly mobile in March and hence more difficult to track.

A few pre-1973 records, mostly gleaned from newspaper columns, are included where they add perspective. Many records were found in seasonal reports and Christmas Bird Counts (CBCs) published in American Birds and elsewhere; others were obtained through personal correspondence and from our own records. It is not feasible to cite individual references for all records. For the most frequent species CBC records from American Birds (recently renamed Audubon Field Notes) are summarized in Table 1.

\section{Annotated List}

HORNED LARK - Regular marginal wintering species. Occurring mainly along roadsides in farmland and prairie. Little time elapses between CBC stragglers and February migrants; some birds overwinter, mainly in the southwest, when snowcover is sparse. In 1993-94 flocks of 20-30 birds were seen throughout the winter in southwestern Manitoba. In other years midwinter irruptions have been noted during prolonged mild spells.

STELLER'S JAY - Accidental vagrant? There were unconfirmed reports in Winnipeg 25 January 1962 and near Beausejour 19 December 1970. We have insufficient details to evaluate these reports; this species is not yet included on the Manitoba list.

SCRUB JAY - Accidental vagrant. Manitoba's first and Canada's second Scrub Jay frequented a Fisher Branch feeder between about $6 \mathrm{De}$ cember 1988 and 8 February 1989, and was photographed. ${ }^{9}$

CLARK'S NUTCRACKER - Accidental vagrant? An unconfirmed report at Hazelridge in February 1930 has been deleted in the copy of the newspaper column in the Manitoba Museum of Man and Nature files. ${ }^{11}$ This species is accepted on the Manitoba list but we have insufficient information to evaluate this report.

AMERICAN CROW - Regular marginal wintering species. Individuals and small groups overwinter near farmyards, at garbage dumps, and in urban areas, mainly south of $51^{\circ} \mathrm{N}$ latitude. Occasionally, substantial flocks have been observed (e.g. 85 birds at Sprague 13 February 1994).

RED-BREASTED NUTHATCH Sporadic marginal wintering species. Often in or near dense coniferous woods. Highest numbers are associated with heavy crops of white spruce cones; a few visit feeders annually. The winter survival rate appears to be high.

BROWN CREEPER - Regular straggler. Wintering status unclear. Creepers occur regularly in spruce forest in December; most are probably late migrants but possible overwintering is difficult to monitor. Few Creepers visit feeders but three overwintered in 1988-89; two in Winnipeg and one at Birds Hill Provincial Park.

MARSH WREN - Accidental straggler. One was seen skulking in a cattail stand at Proulx Lake 2 December 1977. 
GOLDEN-CROWNED KINGLET Regular straggler. Wintering status unclear. As with Brown Creeper many December records may be late migrants; this species does not visit feeders and is hard to monitor at low densities in the extensive coniferous forest where it most frequently occurs.

RUBY-CROWNED KINGLET - Accidental straggler. A report at Lyleton 26 December 1978, by an experienced observer, is nearly two months later than any other record of this species.

EASTERN BLUEBIRD - Accidental straggler. Seen at Dominion City 5 December 1948. One was seen alive at Pine Falls on 14 December 1929 and subsequently found dead on 26 December. $^{14}$

\section{MOUNTAIN BLUEBIRD - Occa-}

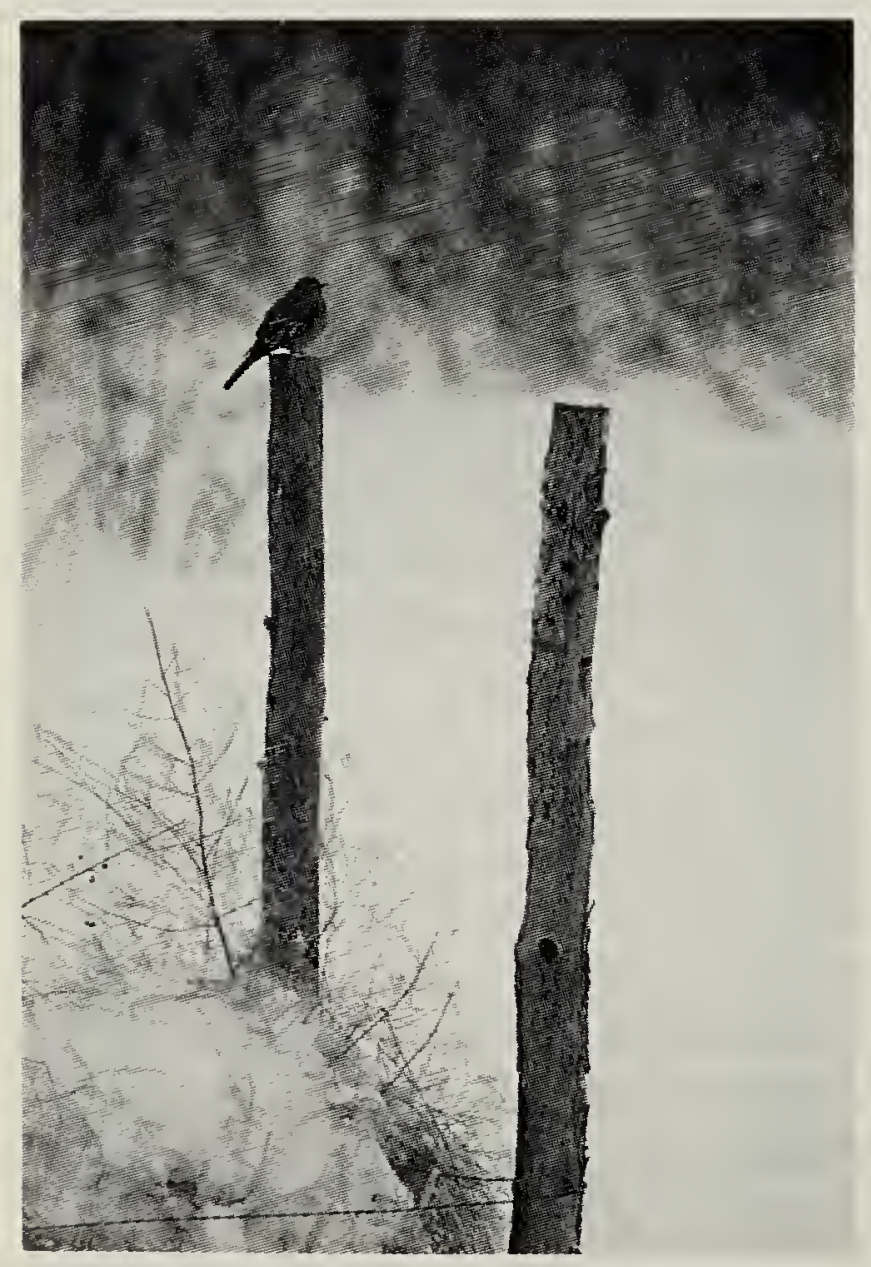

Townsend's Solitaire near Kleefeld, MB, 22 November 1986

Rudolf Koes sional straggler. The latest of four sightings occurred at Devil's Punch Bowl, Spruce Woods Provincial Park (Glenboro - Spruce Woods CBC) 2 January 1988. In mild winters the first "spring" migrants sometimes appear before the end of February.

\section{TOWNSEND'S SOLITAIRE - Occa-} sional vagrant. Eastbound fall wanderings have led to four December records as well as overwintering attempts at Winnipeg (2 February 1983 and late January 1994) and Brandon (9-16 February 1983).

HERMIT THRUSH - Accidental straggler. One was reported on Winnipeg CBCs in 1983 and 1993. The 1983 bird was seen in dense woods along the Assiniboine River and the 1993 bird was in a suburban backyard; both were well described.

WOOD THRUSH - Accidental straggler? An extraordinary report of this neotropical migrant on the 1984 Winnipeg CBC was supported by a fairly convincing sketch but the bird was not found again.

AMERICAN ROBIN - Regular straggler. Mainly outside the boreal forest. A few Robins linger into December each year in southern Manitoba. Most disappear around the New Year but some overwinter when heavy fruit crops are combined with relatively mild conditions.

VARIED THRUSH - Rare vagrant, occasionally overwintering. A few Varied Thrushes occur annually in Manitoba, mainly in late fall and early winter. Of 39 that lingered into December, 10 are known to have overwintered. As with Robins, success depends on ample food, adequate shelter, and moderate weather. Varied Thrushes appear to be more inclined than Robins to visit feeders in addition to fruit trees. 


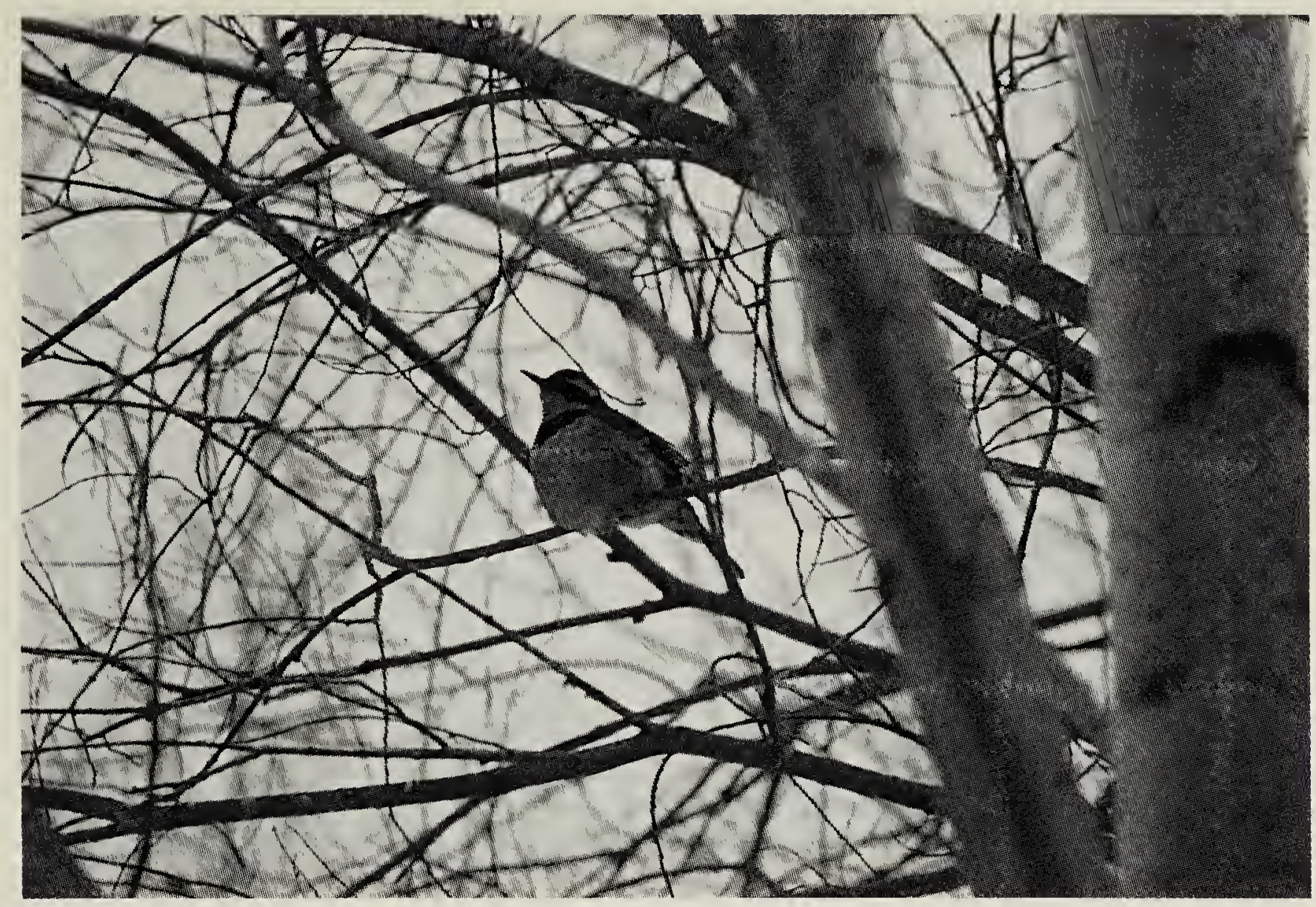

Male Varied Thrush at Pinawa, MB, 26 November 1989

Rudolf Koes

GRAY CATBIRD - Accidental straggler? We have no details of a reported sighting 21 December 1957. Several recent mid-November records lend credence to this report.

NORTHERN MOCKINGBIRD - Occasional straggler. Manitoba lies at the extreme edge of this species' permanent range. There are six December records around Winnipeg, and one Mockingbird overwintered at Pointe du Bois, 1982-83 on a diet of fruit and table scraps. ${ }^{14}$

BROWN THRASHER - Occasional straggler. Ten winter records include four known overwintering successes; at Winnipeg and Sanford 1982-83, Winnipeg 1987-88, and Pinawa 1989-90. Another survived in Winnipeg until at least 25 February 1987. In at least two cases overwintering success depended on very dedicated feeder operators who provided a fat-rich diet.

CEDAR WAXWING - Sporadic, marginal wintering species. Mainly outside the boreal forest. Sometimes hundreds overwinter in Winnipeg, Brandon and other towns in southwestern Manitoba; they may outnumber the more "winterized" but erratic Bohemian Waxwing. In Winnipeg they feed mainly on cultivated fruit trees and occasionally also eat dead cankerworm moths.

LOGGERHEAD SHRIKE - Accidental straggler. One on Dauphin CBC 21 December 1985; we have no details of this sighting.

CAPE MAY WARBLER - Accidental straggler. One at a suet feeder in Seven Sisters Falls to 12 December 1987; this bird disappeared after a snowstorm. $^{16}$

NORTHERN CARDINAL - Rare permanent resident and vagrant. Twenty-eight records include at least eight males and 10 females; most overwintered successfully at feeders. Most were in or near Winnipeg with outliers at Pine Falls 1975-76, Pin-awa 1989-90 and Swan River 1989-90. 


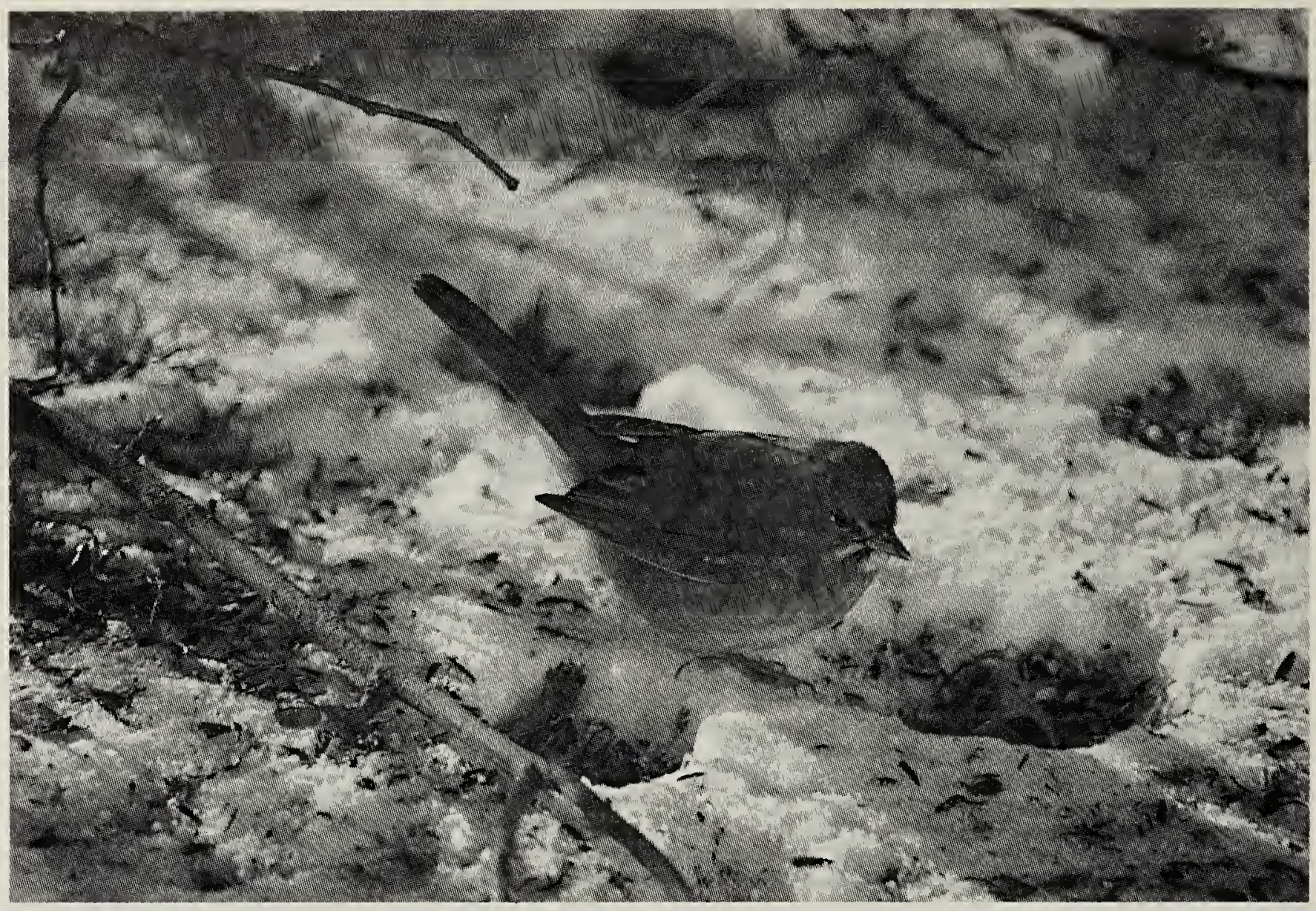

Green-tailed Towhee near Altona, MB, December 1981

Peter Taylor

An ambitious pioneer was at Thompson 17+ December 1988 .

ROSE-BREASTED GROSBEAK -
Accidental straggler? Of three reports at Pinawa two are probably erroneous. One was convincing but may have involved a released bird. ${ }^{14}$

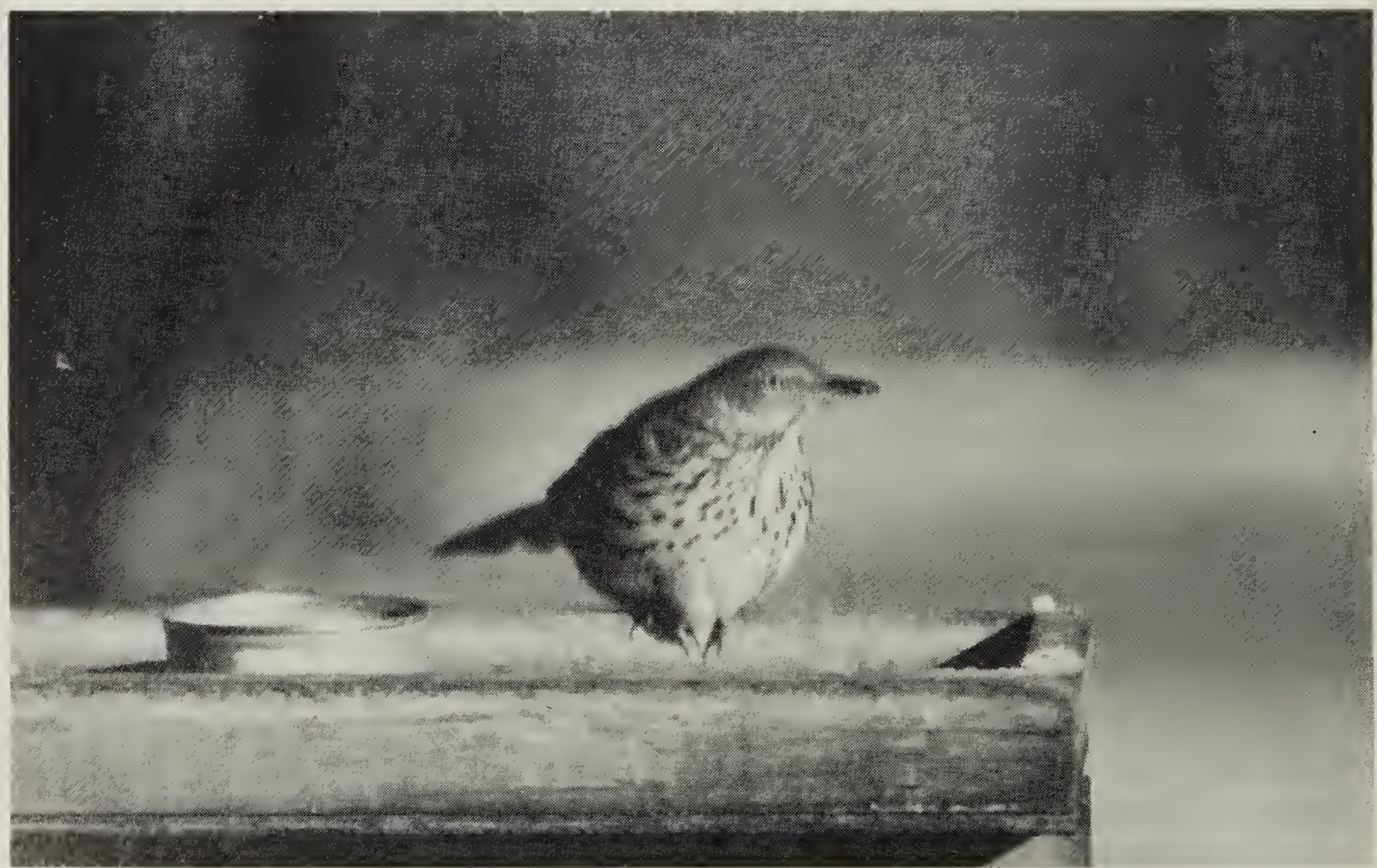




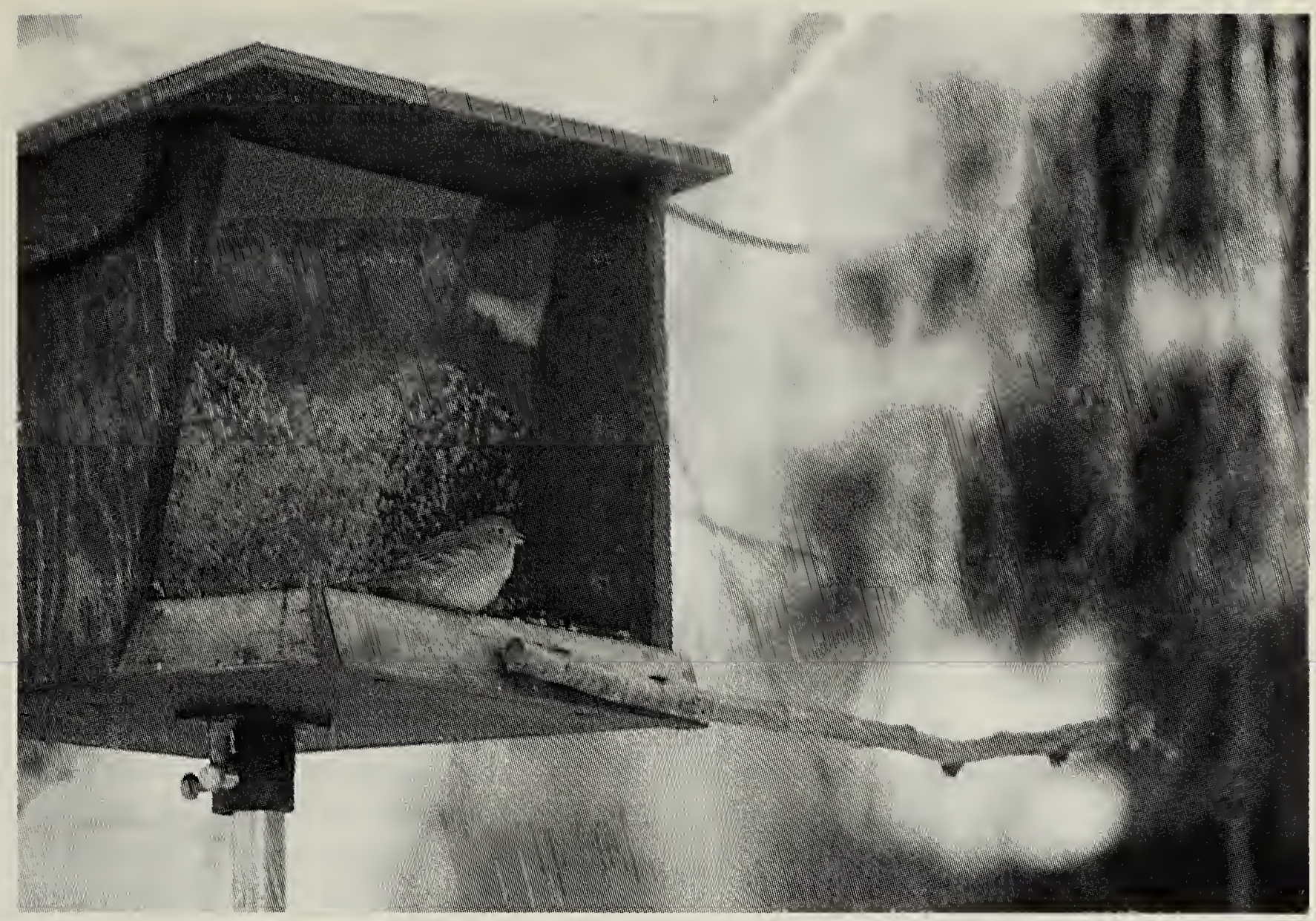

Field Sparrow at a Winnipeg, MB, feeder, 15 January 1989

Rudolf Koes

There are a few recent, authentic November records in Manitoba.

GREEN-TAILED TOWHEE - Accidental vagrant. One bird, Manitoba's first ever, visited a feeder near Altona from 30 November 1981 to 4 January 1982; it apparently succumbed in a severe cold spell. ${ }^{7}$

RUFOUS-SIDED TOWHEE - Occasional straggler. Nine records include successful overwintering at feeders in Winnipeg 1980-81, Sanford 1982-83 and Brandon 1987-88. One at Pinawa, 1978-79, did not survive beyond about 12 January and one at Cypress River, 1985-86, also perished in early January.

AMERICAN TREE SPARROW Rare straggler. Overwintering status unknown. This sparrow is a regular winter species as close as central Minnesota but it is not a frequent feeder user and Manitoba winter records are surprisingly scarce. There are $13 \mathrm{CBC}$ records of up to six birds and a few other early winter records. The latest winter date is 4 February 1990 at Victoria Beach.

CHIPPING SPARROW - Accidental straggler. ${ }^{15}$ One overwintered at Pinawa feeders, 1982-83, and one remained in Winnipeg until at least 27 January 1985.

FIELD SPARROW - Accidental vagrant. One frequented a Winnipeg feeder from December 1988 to February 1989. This species is very rare in Manitoba at any season although nesting has been reported.

VESPER SPARROW - Accidental straggler. One bird seen along a roadside at Dauphin 7 December 1980 appeared to be in good condition. One was observed in an open woodlot on the Melita CBC 18 December 1993 and another was reported on the Brandon CBC $19 \mathrm{De}$ cember 1993.

LARK BUNTING - Accidental 
vagrant. One in Winnipeg 2-5 December 1975: this bird was an odd sight indeed in a city parking lot. ${ }^{6}$

FOX SPARROW - Occasional straggler. Seven winter reports include successful overwintering at Balmoral 1980-81, Brandon 1987-88 and Pinawa 1992-93, all at feeders.

SONG SPARROW - Occasional straggler. Usually visiting feeders. About ten recent winter reports include one overwintering success at St. Norbert, 1989-90. Thompson cites a winter observation by C.W. Nash at a stable near Portage la Prairie on 30 December 1885: one of the first Manitoba reports of the winter straggler phenomenon. ${ }^{17}$

SWAMP SPARROW - Accidental straggler. One was carefully observed in an open woodlot near a yard on the Melita CBC on $18 \mathrm{De}$ cember 1993.

WHITE-THROATED SPARROW Regular straggler. This is the second most frequent emberizine species at Manitoba feeders in winter after Dark-eyed Junco. Successful overwintering has been reported several times.

WHITE-CROWNED SPARROW Occasional straggler. Five feeder reports include one overwintering at Balmoral 1980-81 and one in Winnipeg until 15 February 1992.

HARRIS'S SPARROW - Rare straggler. At bird feeders, spilled grain and cattle self-feeders. Twentyeight reports include five known overwintering successes and three birds surviving until February at least but one died at Delta on 20 January 1982. Unusually far north were CBC records at Thompson in 1987 and The Pas (two birds) in 1990.
DARK-EYED JUNCO - Regular, marginal wintering species. Table 1 attests to this species' frequent occurrence in small numbers, mainly at feeders, but also around farmyards in the southwest. There is some evidence that migration continues into December but there are many records of successful overwintering. Most juncos in Manitoba belong to the "Slate-coloured" form but there are 10 winter records of "Oregon" Juncos and lone "Gray-headed" Juncos overwintered in Winnipeg, 196364 and 1984-85. Also notable was an overwintering attempt by two juncos at Churchill, 1957-58. So far north, survival by one bird until early March does not really qualify as successful overwintering, especially when predation by a Gyrfalcon was suspected! ${ }^{4}$

LAPLAND LONGSPUR - Sporadic, marginal wintering species. This species usually vacates the province in winter but large numbers are occasionally seen in or near the Red River valley; e.g. 215 near Kleefeld on 1 January 1982, 500 in unharvested grain near Morris on 16 January 1994 and 500 in an alfalfa field near Kleefeld on 15 January 1995. Small numbers are occasionally noted elsewhere. Early migrants. sometimes return to southwestern Manitoba before the end of February.

\section{RED-WINGED BLACKBIRD -}

Regular straggler. Redwings usually occur singly but small flocks sometimes linger in the southwest. The Lyleton CBC total of 45 in 1990 was exceptional. Wintering attempts, with some success, have been noted at feeders, dumps and cattle feedlots.

WESTERN MEADOWLARK - Rare straggler. There are at least 15 records of meadowlarks (presumed Western) in late December or early January. Individuals overwintered at 
Table 1. SUMMARY OF RARE AND MARGINAL SPECIES RECORDED ON AT LEAST 10 OF THE 221 MANITOBA CHRISTMAS BIRD COUNTS PUBLISHED IN AMERICAN BIRDS AND AUDUBON FIELD-NOTES, 1973-1994.

\begin{tabular}{|c|c|c|c|c|}
\hline \multirow[b]{2}{*}{ Species } & \multicolumn{3}{|c|}{ Number of Records } & \multirow{2}{*}{ Highest Count $^{b}$} \\
\hline & Years & Location & Counts & \\
\hline Horned Lark & 19 & 11 & 41 & 40, Delta, 1994 \\
\hline American Crow & 21 & 14 & 81 & 139, Winnipeg, 1994 \\
\hline Red-breasted Nuthatch & 20 & 15 & 99 & 60, RMNP ${ }^{\mathrm{a}}, 1991$ \\
\hline Brown Creeper & 18 & 10 & 39 & 7, RMNP, 1974 \\
\hline Golden-crowned Kinglet & 17 & 12 & 52 & 59, RMNP, 1974 \\
\hline American Robin & 21 & 15 & 57 & 33, Winnipeg, 1989 \\
\hline Cedar Waxwing & 19 & 16 & 72 & 307, Minnedosa, 1988 \\
\hline American Tree Sparrow & 9 & 7 & 12 & 6, Lyleton, 1994 \\
\hline White-throated Sparrow & 16 & 12 & 36 & 7, Winnipeg, 1991 \\
\hline Dark-eyed Junco & 21 & 18 & 135 & 71, Winnipeg, 1989 \\
\hline Lapland Longspur & 8 & 8 & 18 & 63, Winnipeg, 1985 \\
\hline Red-winged Blackbird & 17 & 15 & 60 & 45, Lyleton, 1990 \\
\hline Rusty Blackbird & 19 & 12 & 54 & 26, Rivers, 1993 \\
\hline Brewer's Blackbird & 13 & 9 & 27 & 8, Delta, 1989 \\
\hline Common Grackle & 19 & 14 & 73 & 10. Winnipeg, 1974 \\
\hline Purple Finch & 17 & 13 & 44 & 30, Cypress River, 1988 \\
\hline Pine Siskin & 19 & 17 & 89 & 3282, Glenboro, 1994 \\
\hline American Goldfinch & 14 & 14 & 40 & 584, Delta, 1979 \\
\hline
\end{tabular}

Brandon and near Beausejour, 198687. Others may well have survived Manitoba winters, huddled among cattle in feedlots. Migrants returned to southwestern Manitoba before the end of February 1981.

YELLOW-HEADED BLACKBIRD Occasional straggler. There are four CBC records but we have no evidence of successful overwintering.

\section{RUSTY BLACKBIRD - Regular} straggler. Most frequently reported in the southwest, sometimes in small flocks ( birds) and almost invariably among cattle in feedlots. Some probably overwinter successfully; nine were seen at Rivers on 12 February 1983 and one of two noted on the 1978 Cypress River CBC was still present in March 1979.

BREWER'S BLACKBIRD - Regular straggler. Reported less frequently than Rusty Blackbird. Overwintering was reported at Riding Mountain
N.P. 1978-79, Rennie 1979-80 and Kleefeld 1991-92. More information is needed on the comparative wintering occurrence and success of this species and other blackbirds.

COMMON GRACKLE - Regular straggler. This is the most widespread blackbird in winter and by far the most frequent in extreme southeastern Manitoba. It is recorded mainly at feeders, sometimes in groups of up to five birds. Overall wintering success is probably below $50 \%$.

\section{BROWN-HEADED COWBIRD -} Occasional straggler. There are four December reports with no evidence of overwintering. One of these was observed inside the Ogilvie Flour Mill on the Winnipeg CBC, 20 December 1980. This species normally leaves Manitoba in August and should therefore be identified with caution in winter. 


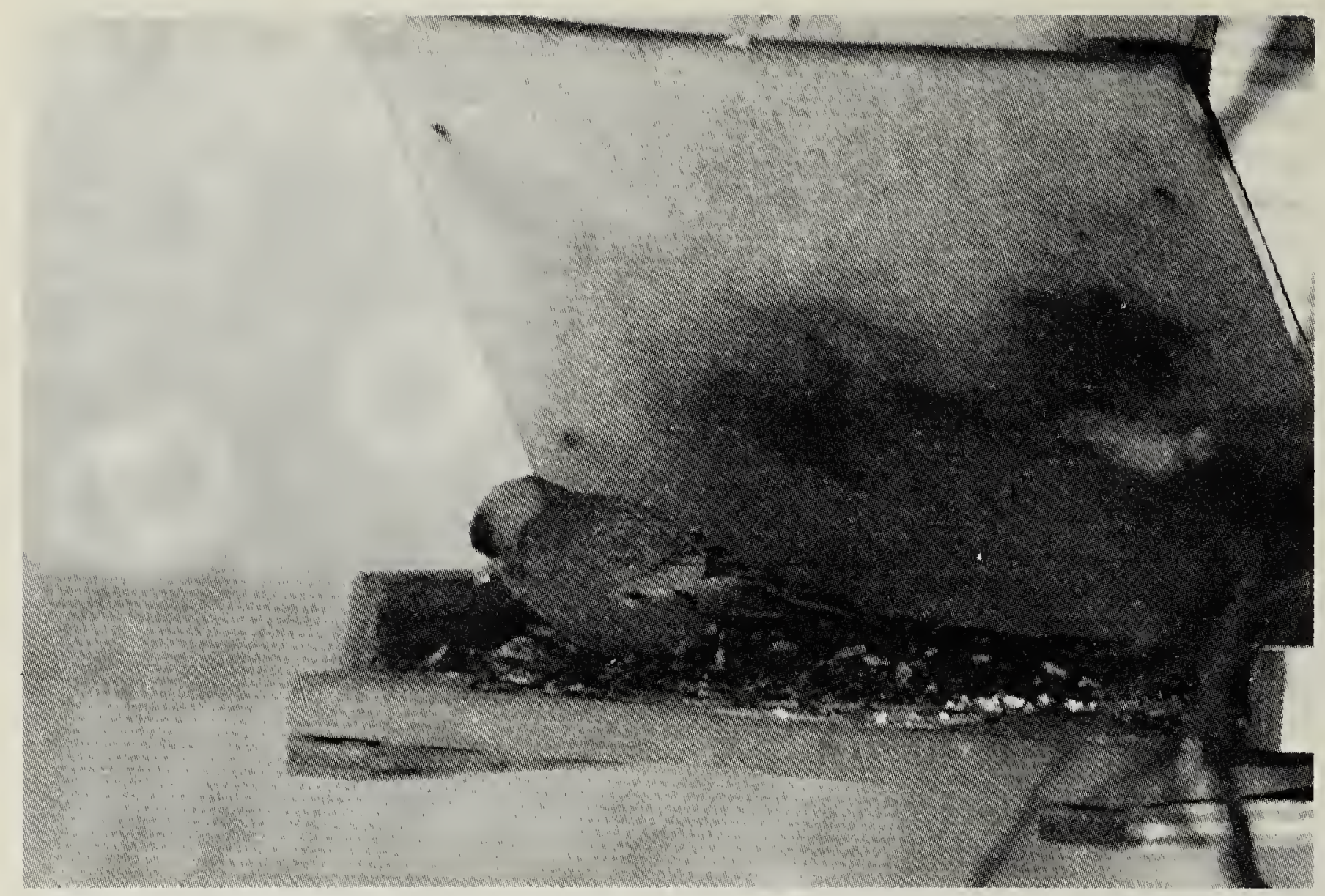

Peter Taylor

NORTHERN ORIOLE - Accidental straggler in Winnipeg to 16 December 1987. A male fed on crabapples in a suburban backyard but disappeared after the first real cold spell.

BRAMBLING - Accidental vagrant. Several records of this Eurasian finch in western North America, 1993-94, included three visitors to Manitoba bird-feeders: one at Portage la Prairie, 15 December to midJanuary, and two at Bethany, 8-14 January, one of which remained until at least 21 February.

GRAY-CROWNED ROSY FINCH Occasional vagrant. Thirteen Manitoba records of this wanderer from the Rockies include seven in winter months; most were reviewed by Turner and Taylor. ${ }^{18}$ Two have overwintered at Pinawa feeders, 1978-79 and 1987-88. A feisty attitude enabled them to compete effectively with Pine and Evening Grosbeaks. In contrast, a bird found in Winnipeg on
22 December 1977 appeared weak when last seen on 8 January 1978.

PURPLE FINCH - Regular straggler. A few occur at Manitoba feeders each winter, usually singly but occasionally in small flocks: e.g. 14 at Victoria Beach 16 January 1993 and a total of 30 at three feeders on the 1988 Cypress River CBC. The overwintering success rate appears to be high.

HOUSE FINCH - Regular straggler? The status of this feeder species in Manitoba is still evolving rapidly. ${ }^{2,13}$ One possibly overwintered in Brandon, 1991-92, and at least three overwintered in Altona, 1992-93. The 1993 CBC totals included 32 in Winnipeg and 19 in Brandon but there was some evidence that many of these birds withdrew from the province in January. The 1994 CBC totalled 192 birds on eight counts in southcentral and southwestern Manitoba, all at feeders. 


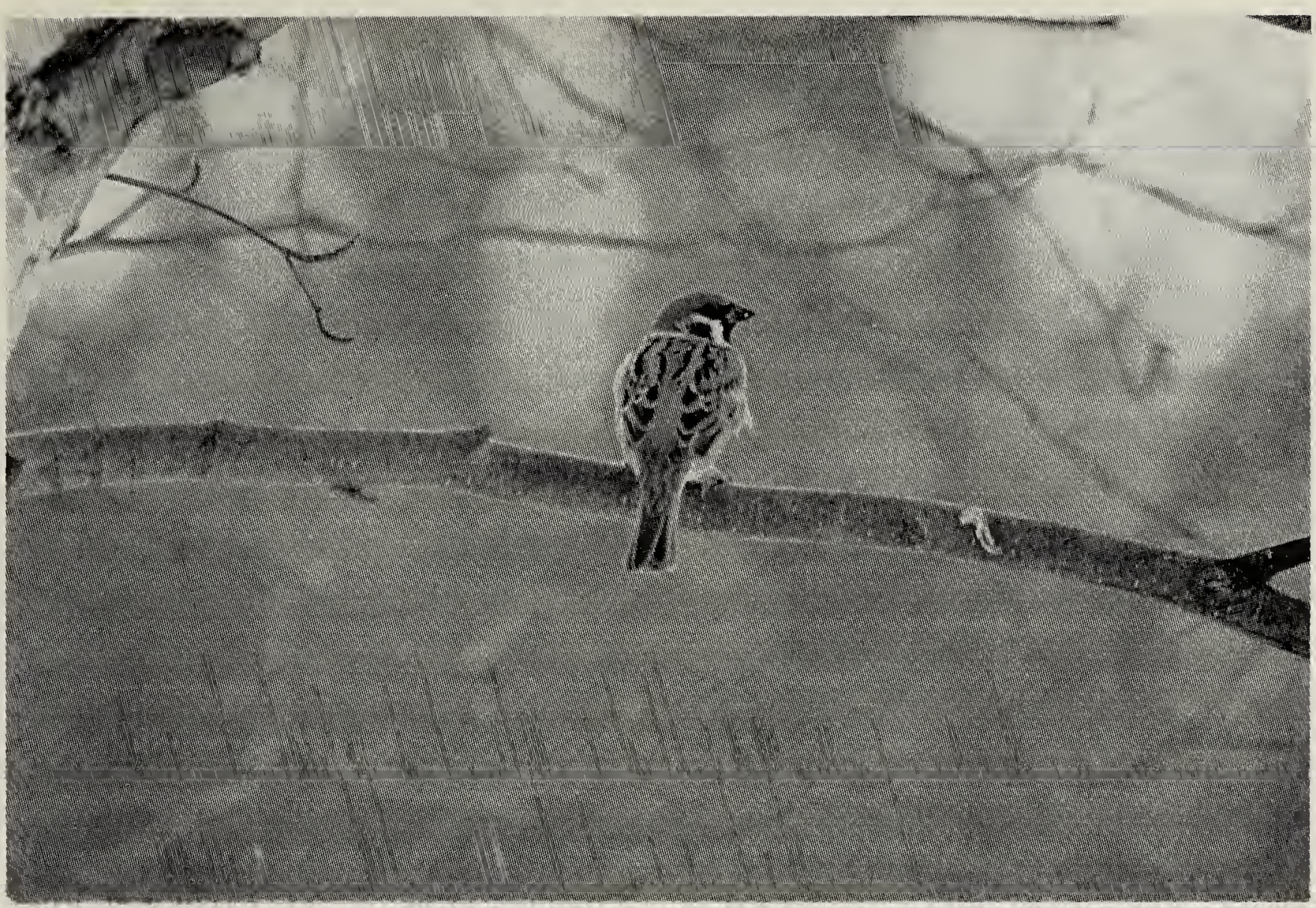

PINE SISKIN - Sporadic, marginal winter species. The winter frequency and abundance of Pine Siskins in Manitoba have increased dramatically in the last 20 years. CBC totals in the hundreds are now almost commonplace in some areas. Hundreds or even thousands remain throughout the winter in peak years. In southwestern Manitoba they frequent grain piles, sunflower fields, weed patches and feeders. In the southeast they feast on birch seeds during mild spells and concentrate at feeders when it is cold. Heavy mortality was reported in parts of southern Manitoba in 1987-88, whereas midwinter mobility was indicated by fluctuating numbers and distribution in 1992-93.

\section{AMERICAN GOLDFINCH - Spo-} radic, marginal winter species. Goldfinches were considered rare in winter in Manitoba until the 1979-80 invasion when thousands thronged feeders, sunflower fields and seedladen birch trees across the south. A more limited invasion occurred in
1982-83, and small numbers are now reported almost annually, mainly at feeders.

\section{EURASIAN TREE SPARROW -} Accidental vagrant. An individual arrived at a feeder at St. Francis Xavier on 2 November 1986 and finally succumbed during its fifth winter around 22 January $1991 .^{8,9}$ It made the best of its isolation and was survived by hybrid House Sparrow $X$ Eurasian Tree Sparrow progeny. ${ }^{10}$

Summary The number of species and individuals of marginal and straggling winter passerine birds in Manitoba appears to be increasing. For example, 12 of the 18 highest counts shown in Table 1 were recorded between 1988 and 1994 . Many of the species discussed. above were found wintering in Manitoba for the first time in the 1970s or 1980s. Several factors may be contributing to this phenomenon. Most obvious is the number of bird feeders, both in urban and rural areas. Also important is the cultivation of 
specialty crops such as sunflowers and flax. The former often entices American Crows, blackbirds and American Goldfinches, and the latter Lapland Longspurs. Plantings of conifers outside the boreal forest are often used by Red-breasted Nuthatches, Brown Creepers and Golden-crowned Kinglets for foraging and by other species, such as sparrows, for shelter. We recognize that the apparent increase in some of these species may be a consequence of higher observer effort. For example, the number of CBCs has probably tripled in the last 20 years, more observers are afield in the winter, and reporting methods have improved.

We hope this article will provide a benchmark for detecting future changes in winter bird distribution which may result from long-term changes in climate (e.g. global warming), food supply, habitat or behaviour. We also hope it may stimulate more detailed reviews of the winter status of individual species in the Prairie Provinces.

Acknowledgement We thank Ken De Smet who made helpful comments on a draft manuscript and clarified the status of several species in southwestern Manitoba.

1. ARMSTRONG, E.R. and D.L.G. NOAKES. 1983. Wintering biology of Mourning Doves, Zenaida macroura, in Ontario. Can. Field-Nat. 97:434438.

2. BANCROFT, J. and R.J. PARSONS. 1991. Range expansion of the House Finch into the Canadian Prairie Provinces. Blue Jay 49:128-136.

3. BLOM, E. 1987. The changing seasons. American Birds 41:248-252.

4. JEHL, J.R. Jr. and B.A. SMITH. 1970. Birds of the Churchill Region, Manitoba. Spec. Publ. No. 1, Manitoba Museum of Man and Nature, Winnipeg.
5. KAUFMANN, K. 1992. The changing seasons: winter 1991-1992. American Birds 46:224-227.

6. Knapton, R.W. 1976. A winter Lark Bunting in Winnipeg. Blue Jay 34:237.

7. KOES, R.F. 1985. Additions to the Manitoba bird list (1975-1984). Blue Jay 43:224-231.

8. KOES, R.F. 1988. Eurasian Tree Sparrow in Manitoba. Blue Jay 46:3435.

9. KOES, R.F. 1992. Additions to the Manitoba bird list (1985-1990). Blue Jay 49:202-207.

10. LANG, A. 1992. The Eurasian Tree Sparrow population in North America: evolving and expanding. Birders Journal 1:298-307.

11. LAWRENCE, A.G. 1930. Chickadee Notes No. 479. Winnipeg Free Press, 30 May 1930.

12. MANITOBA AVIAN RESEARCH COMMITTEE (MARC). 1986. Field checklist of the birds of Manitoba. Manitoba Museum of Man and Nature and Manitoba Naturalists Society, Winnipeg.

13. PARSONS, R.J. and J.I. HORTON. 1993. First nesting records of the House Finch in Manitoba. Blue Jay 51:113-121.

14. TAYLOR, P. 1983. Wings along the Winnipeg: the birds of the Pinawa Lac du Bonnet Region, Manitoba. Manitoba Naturalists Society, Winnipeg. Eco Series No. 2. Reprinted with minor revisions, 1985 .

15. TAYLOR, P. 1984. A wintering Chipping Sparrow at Pinawa, Manitoba. Blue Jay 42:52-53.

16. TAYLOR, P. 1988. Cape May Warbler in Manitoba in December. Blue Jay 46:160-162.

17. Thompson [SETON], E.E. 1891. The birds of Manitoba. Proc. U.S. Natl. Mus. 13:457-643.

18. TURNER, B.N. and P. TAYLOR. 1980. The Gray-crowned Rosy Finch in Manitoba and vicinity. Blue Jay 38 : 238-245. 